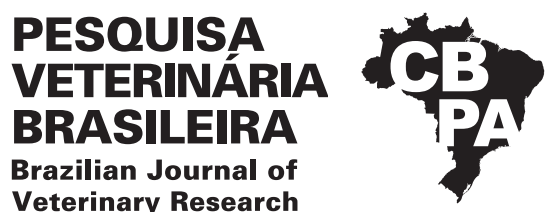

Pesq. Vet. Bras. 41:e06655, 2021

DOI: 10.1590/1678-5150-PVB-6655

Original Article

Veterinarv Research

ISSN 0100-736X (Print)

Small Animal Diseases

ISSN 1678-5150 (Online)

\title{
Accuracy of B-mode ultrasonography for detecting malignancy in canine cutaneous neoplasms: preliminary results ${ }^{1}$
}

\author{
Igor C.K. da Cruz ${ }^{2 *}$, Maria L.A. Mestieri ${ }^{3}$ (D), João P.E. Pascon ${ }^{3}$ (D), \\ Mauren P. Emanuelli ${ }^{3}$ (D), Maria E. Trost ${ }^{3}$ (D), Etiele M. Gomes ${ }^{3}$ (D) \\ and Ingrid R.L. Machado ${ }^{3}$ (iD
}

\begin{abstract}
Cruz I.C.K., Mestieri M.L.A., Pascon J.P.E., Emanuelli M.P., Trost M.E., Gomes E.M. \& Machado I.R.L. 2021. Accuracy of B-mode ultrasonography for detecting malignancy in canine cutaneous neoplasms: preliminary results. Pesquisa Veterinária Brasileira 41:e06655, 2021. Laboratório de Ultrassonografia Veterinária, Universidade Estadual Paulista "Júlio de Mesquita Filho", Via de Acesso Prof. Paulo Donato Castellane s/n, Jaboticabal, SP 14884-900, Brazil. E-mail: igor_113@hotmail.com

The aim of this study was to verify the applicability and accuracy of B-mode ultrasonography in detecting malignancy in dog cutaneous neoplasms. Forty-two neoplasms (12 benign and 30 malignant) of mesenchymal, round cells, epithelial and melanocytic origins from 24 dogs of different breeds and ages were included. The ultrasound evaluation was performed with a linear multi-frequency transducer $(7.0$ to $12 \mathrm{MHz})$, with frequency dependent on the mass dimension. Ultrasonographic characteristics of echogenicity (hypo/hyperechogenic), echotexture (homogeneous/heterogeneous), regularity, invasiveness in adjacent tissues were classified. Dimensions were also measured to calculate the depth/width ratio. Neoplasms were classified as malignant or benign after cytological and/or histopathological analysis and the results were associated with ultrasound characteristics. There was a significant association $(P<0.05)$ between malignancy and echogenicity, echotexture and invasiveness in adjacent tissues, so that $84.6 \%$ of hypoechogenic neoplasms, $76.9 \%$ of heterogeneous masses and $88.2 \%$ of invasive neoplasms were classified as malignant. However, for all these associations, moderate predictive values were obtained, which may be due to the small experimental number included in this study. Therefore, although it has been observed that hypoechogenic, heterogeneous and invasive neoplasms were more prone to malignancy, these findings should be used with caution until new studies are developed with a greater number and variety of cutaneous neoplasms in dogs.
\end{abstract}

INDEX TERMS: B-mode, ultrasonography, canine, cutaneous neoplasms, dogs, malignancy.

RESUMO.- [Acurácia da ultrassonografia modo-B na detecção de malignidade em neoplasmas cutâneos de caninos: resultados preliminares.] 0 objetivo deste estudo foi verificar a aplicabilidade e acurácia da ultrassonografia modo-B na detecção de malignidade em neoplasmas cutâneos de cães. Foram incluídos 42 neoplasmas (12 benignos e 30

\footnotetext{
${ }^{1}$ Received on August 18, 2020.

Accepted for publication on September 4, 2020.

${ }^{2}$ Laboratório de Ultrassonografia Veterinária, Universidade Estadual Paulista "Júlio de Mesquita Filho" (Unesp), Via de Acesso Prof. Paulo Donato Castellane s/n, Jaboticabal, SP 14884-900, Brazil. *Corresponding author: igor_113@hotmail.com

${ }^{3}$ Universidade Federal do Pampa (Unipampa), BR-472 Km 585, Uruguaiana, RS 97501-970, Brazil.
}

malignos) de origens mesenquimal, células redondas, epitelial e melanocítica provenientes de 24 cães de diferentes raças e idades. 0 exame ultrassonográfico foi realizado com transdutor linear multifrequencial ( 7.0 a $12 \mathrm{MHz}$ ), com frequência dependente da dimensão da massa. Foram classificadas características ultrassonográficas de ecogenicidade (hipo/ hiperecogênicos), ecotextura (homogêneos/heterogêneos), regularidade, invasividade em tecidos adjacentes. As dimensões foram mensuradas para cálculo da razão profundidade/largura. Os neoplasmas foram classificados como malignos ou benignos após análise cito e/ou histopatológica e os resultados foram associados com as características ultrassonográficas. Verificouse associação significativa $(P<0.05)$ entre malignidade e ecogenicidade, ecotextura e invasividade em tecidos adjacentes, 
de forma que $84.6 \%$ dos neoplasmas hipoecogênicos, 76.9\% das massas heterogêneas e $88.2 \%$ dos neoplasmas invasivos foram classificados como malignos. Entretanto, para todas essas associações, foram obtidos valores preditivos moderados, que podem ser decorrentes do baixo número experimental incluso neste estudo. Sendo assim, embora tenha sido observado que os neoplasmas hipoecogênicos, heterogêneos e invasivos tiveram maior propensão à malignidade, esses achados devem ser utilizados com cautela até novos trabalhos sejam desenvolvidos com maior número e variedade de neoplasmas cutâneos de cães.

TERMOS DE INDEXAÇÃO: Ultrassonografia, modo-B, malignidade, neoplasmas cutâneos, caninos, cão.

\section{INTRODUCTION}

Cutaneous neoplasms are frequent in the veterinary clinical routine, representing 10-20\% of canine neoplasia (Dobson \& Scase 2007, Merlo et al. 2008). It includes several different malignant and benign tumors (Villamil et al. 2011, Graf et al. 2018). The diagnose is ideally based on histopathological features (Graf et al. 2018) and that can lead to the late on treatment or mistakes on surgical planning.

The ultrasound evaluation of cutaneous neoplasms is widespread in medicine and the method is already implemented in the clinical routine in the differentiation between benign/ malignant neoplasms, inflammatory and infectious diseases (Kleinerman et al. 2012). Although this method does not replace the histopathological exam, it has been established that cutaneous melanomas, squamous cell carcinomas and human basal cell carcinomas are hypoechogenic and surrounded by a hyperechogenic structure (Barcaui et al. 2014).

Ultrasonography is a non-invasive technique that provides results in real time and the characteristics referring to different human cutaneous neoplasms are already established. For this reason, ultrasound is used to monitor skin cancer and to guide the clinician regarding therapeutic planning (surgical or not). Furthermore, in cases of melanoma, it also helps in establishing the prognosis using the Breslow's depth (Badea et al. 2010, Kučinskienė et al. 2014, Roldán 2014, Reginelli et al. 2020).

In dogs, ultrasonography has helped to predict malignancy in mammary tumors. It was observed that malignant mammary neoplasms have a higher depth/width ratio and width/height ratio when compared to benign ones (Tagawa et al. 2016, Feliciano et al. 2017). Nevertheless, Tagawa et al. (2016) found that heterogeneous, irregular mammary neoplasms with a pleomorphic shape were more prone to malignancy.

Regarding to canine cutaneous tumors, although few studies have been found demonstrating the applicability of mode B ultrasonography to differentiate neoplasms, the results are encouraging. In a study by Loh et al. (2009), 34 canine cutaneous neoplasms were evaluated, which were divided into three groups: cutaneous mast cell tumors, soft tissue sarcomas and others. It was observed that $100 \%$ of hyperechogenic neoplasms were soft tissue sarcomas. In another study, Longo et al. (2018) were able to differentiate lipomas from malignant cutaneous neoplasms of dogs through their shape, regularity, echogenicity and echotexture.

It is known that early diagnosis supports the establishment of adequate therapy more quickly, aiding therapeutic success in cancer patients (Rosseto et al. 2009). However, considering that cytological exams often present inconclusive or unspecific results (Khalbuss et al. 2010, Simeonov 2010) and that histopathological samples delay longer until the final report (Wahie \& Lawrence 2007), quick and non-invasive methods that can assist the clinician in his planning are important. Thus, the aim of this preliminary study was to verify which ultrasound characteristics had the greatest correlation in the detection of malignancy in different types of cutaneous neoplasms in dogs, as well as to verify the accuracy of this imaging method in the cases studied through the analysis of predictive values.

\section{MATERIALS AND METHODS}

This study was approved by the University's Institutional Animal Care and Use Committee of the "Universidade Federal do Pampa", Uruguaiana/RS, Brazil (Protocol no. 008/2018). Twenty-four dogs of the institution's hospital routine with cutaneous neoplasms were included.

For ultrasonography, trichotomy was performed and the decubitus varied according to the individual anatomical location for each neoplasm. The B-mode study was performed in longitudinal, transverse and oblique sections, using a linear and multifrequency transducer (from 7.0 to $12.0 \mathrm{MHz}$ ) and conductive gel. The frequency selection was inversely proportional to the evaluated mass dimension (the smaller the mass or more superficial, the higher frequency was chosen). The images were obtained by the same ultrasound equipment (LOGIQ P5, GE, United States) and a single experienced evaluator. The sequence of examinations was standardized, so the ultrasound exam was always performed before sampling for definitive diagnosis.

Characteristics of echogenicity (predominantly hypo or hyperechogenic), echotexture (homogeneous or heterogeneous), borders regularity (regular or irregular), invasiveness in adjacent tissues (invasive or noninvasive) and hyperechogenic contour (presence or absence) were evaluated and classified. Depth (cm) and width $(\mathrm{cm})$ dimensions and the depth/width ratio in longitudinal section were measured.

For cytopathological evaluation, samples were collected by fineneedle aspiration cytology (FNAC) or fine-needle cytology (FNC) using a $22 \mathrm{G}$ needle $(0,7 \times 25 \mathrm{~mm})$. The samples were placed on identified glass slides, which were squashed and subsequently stained with fast panoptic for microscopic evaluation (with and without immersion oil) and evaluation of cell type and characteristics. All samples were examined by a single experienced cytopathologist.

For histopathological examinations, samples were obtained after complete tumor excision, with individual surgical and anesthetic protocols. Tumors were fixed in $10 \%$ phosphate buffer formaldehyde solution and routinely processed for histopathology analysis prior to paraffin embedding. Tissue sections $(5 \mu \mathrm{m})$ were mounted onto glass slides and stained with hematoxylin/eosin (HE) and toluidine blue in case of cytopathological diagnosis of mastocytomas. The diagnoses were performed by a single experienced pathologist.

Definitive diagnostics were based on cyto and/or histopathological results. For those presenting both tests, agreement test was performed to increase the reliability of cytopathological results. Such agreement was evaluated by the kappa test and the result obtained was $\mathrm{k}=1.0$ (perfect agreement). After diagnosis, neoplasms were categorized according to malignancy (malignant or benign) based on tumor types.

Statistical analysis was performed using statistical software IBM SPSS Statistics 20 (International Business Machines Corp, São Paulo, 
Brazil) and for all tests 95\% confidence interval was considered $(P \leq 0.05)$. The association between B-mode ultrasound characteristics and tumor malignancy was calculated by Fisher's exact test and logistic regression. After calculating the depth/width ratio, mean and standard deviation of each measurement, a ROC curve was performed to verify if it was also associated with tumor malignancy. For significant associations, values of sensitivity, specificity, accuracy, positive and negative predictive value were calculated.

\section{RESULTS}

Twenty-four dogs (70.8\% females and 29.2\% males) with an average age of 8.7 years ( 2.5 to 14 years) were included. There was a higher frequency of Labrador Retriever dogs (33.33\%), followed by mixed breed dogs (29.17\%) and Poodle $(12.5 \%)$. Of these, fourteen dogs presented a single neoplasm, while ten animals were evaluated for more than one cutaneous tumor. Of dogs with more than one cutaneous neoplasm, just one presented tumors with different diagnoses (one dog presented two mast cell tumors and one benign tumor of epithelial origin).

In total, forty-two cutaneous neoplasms with ten specific types of tumors were evaluated (Table 1). Of these neoplasms, 22 had only cytopathological results, three had only histopathological results, and 17 had both results. The neoplasms were classified into 12 benign and 30 malignant.

Of the 42 cutaneous neoplasms evaluated, 26 were predominantly hypoechogenic (Fig.1A) and 16 predominantly hyperechogenic (Fig.1B). From all hypoechogenic neoplasms, four $(15.4 \%)$ were considered benign and 22 (84.6\%) malignant. The tumors classified as hyperechogenic presented the same number of malignant and benign neoplasms $(n=8)$. A larger proportion of malignant hypoechogenic neoplasms (22 tumors) were observed. The association between hypoechogenicity and malignancy was statistically confirmed (Table 2), showing $73.33 \%$ sensitivity, $66.66 \%$ specificity, $22.19 \%$ accuracy, $84.61 \%$ positive predictive value and $50 \%$ negative predictive value.

The neoplasms were classified into homogeneous $(n=3)$ and heterogeneous $(n=39)$ considering the echotexture. All homogeneous neoplasms (Fig.1C) were diagnosed as benign (two benign epithelial neoplasms and one lipoma). Of the heterogeneous (Fig.1D), there were 30 (76.9\%) malignant and nine $(23.1 \%)$ benign. The association between echotexture and malignancy was statistically confirmed (Table 2), obtaining
100\% sensitivity, 25\% specificity, 30.1\% accuracy, $76.92 \%$ positive predictive value and $100 \%$ negative predictive value.

No statistical relationship was observed between neoplasm regularity (Fig.2) and malignancy (Table 2). There were 29 tumors with regular borders (69.05\%) and 13 irregulars $(30.95 \%)$. Of the regular masses, ten were diagnosed as benign and 19 malignant, while of the irregular neoplasms, 11 were malignant and two benign.

Considering the presence of a hyperechogenic structure surrounding the neoplasms (Fig.2A), 37 neoplasms were positive, while five did not present this finding. In this evaluation, all neoplasms without hyperechogenic contours (five neoplasms) were diagnosed as malignant, but no statistical relationship was detected (Table 2).

Regarding invasiveness in surrounding tissues, there were 17 tumors classified as invasive and 25 noninvasive. Significant statistical results were obtained in the association between this characteristic and malignancy (Table 2), with 50\% sensibility, 83,33\% specificity, 15.23\% accuracy, 88.23\% positive predictive value and $40 \%$ negative predictive value. Of the invasive tumors, only two were benign (one lipoma and one benign peripheral nerve sheath tumor), while the remaining 15 (88.2\%) were diagnosed as malignant.

The ultrasound dimensions of 32 masses (22 malignant and ten benign) were measured. However, there was no association between tumoral malignancy with depth $(1.12 \pm 0.69 \mathrm{~cm})$, width $(2.49 \pm 1.64 \mathrm{~cm})$ and $\mathrm{D} / \mathrm{W}$ ratio $(0.47 \pm 0.13)$ (Table 2$)$.

\section{DISCUSSION}

The present study brings unprecedented preliminary results regarding the prediction of malignancy in cutaneous neoplasms of dogs by two-dimensional ultrasound assessment. It was observed that some ultrasound characteristics were associated with tumor malignancy, so that these results serve as a guide for future investigations, involving a greater number and variety of skin neoplasms.

The association between hypoechogenicity and malignancy of canine cutaneous tumors was observed. Although similar studies in cutaneous neoplasias were not found, in previous study involving mammary tumors (Feliciano et al. 2017) this association was not observed. Tumor growth is associated with presence of inflammatory sites, since edematous tissues can decrease the echogenicity of the parenchyma and present liquid components (Wratten et al. 2007, Figueiredo 2019).

Table 1. Cutaneous neoplasms diagnosed by cytology and/or histology in 24 dogs

\begin{tabular}{|c|c|c|c|c|c|}
\hline Origin & Neoplasm & Malignancy & Cp only & Hp only or both & Total neoplasms \\
\hline \multirow[t]{4}{*}{ Mesenchymal } & Myxoma & Benign & 7 & 0 & 7 \\
\hline & Soft tissue sarcoma & Malignant & 5 & 5 & 7 \\
\hline & Lipoma & Benign & 1 & 2 & 2 \\
\hline & Peripheral nerve sheath tumor & Benign & 1 & 1 & 1 \\
\hline Round cells & Mast cell tumor & Malignant & 14 & 7 & 16 \\
\hline Epithelial & Benign tumor of epithelial origin & Benign & 2 & 0 & 2 \\
\hline Melanocytic & Melanoma & Malignant & 1 & 1 & 1 \\
\hline TOTAL & - & - & 35 & 18 & 42 \\
\hline
\end{tabular}

(-) Not applicable; $\mathrm{Cp}=$ cytophatologym, $\mathrm{Hp}=$ histopathology. 
The heterogeneity seen in malignant neoplasms may be justified by their growth and aggressiveness characteristics, so that there is often a loss of cellular architecture pattern, spiculations or calcifications (Feliciano et al. 2008). In the present study, the association between heterogeneous features and malignancy was also noticed in cutaneous tissue. Feliciano et al. (2012) demonstrated the association between heterogeneity of female mammary neoplasms and malignancy, but this study also verified that some benign neoplasms presented heterogeneous echotexture. Moreover, Garcia et al. (2012) correlated interspersed pattern and malignant septations in parenchymal abdominal organ neoplasms.

Heterogeneous echotexture may be justified by some histopathological features, such as irregular nuclei and/or intense inflammatory infiltrate. These histological findings are more prevalent in malignant tumors, but they may also occur in some benign neoplasms (Veronese et al. 2007).

Tumor regularity has been previously cited as a predictor of malignancy in mammary neoplasms (Nyman et al. 2006). However, no association between regularity and neoplastic malignancy was observed in this study. This feature should be further evaluated in order to define if it can be related to some cutaneous neoplasia of specific origins or if it would be not helpful on prediction of tumor malignancy in skin.

No association of absence hyperechogenic contours and malignancy was detected. Considering that hyperechogenic contours are derived from the presence of capsules, and that encapsulated neoplasms usually present slower growth, it would be hypothesized that it is directly associated with benignity. However, some malignant neoplasms may show
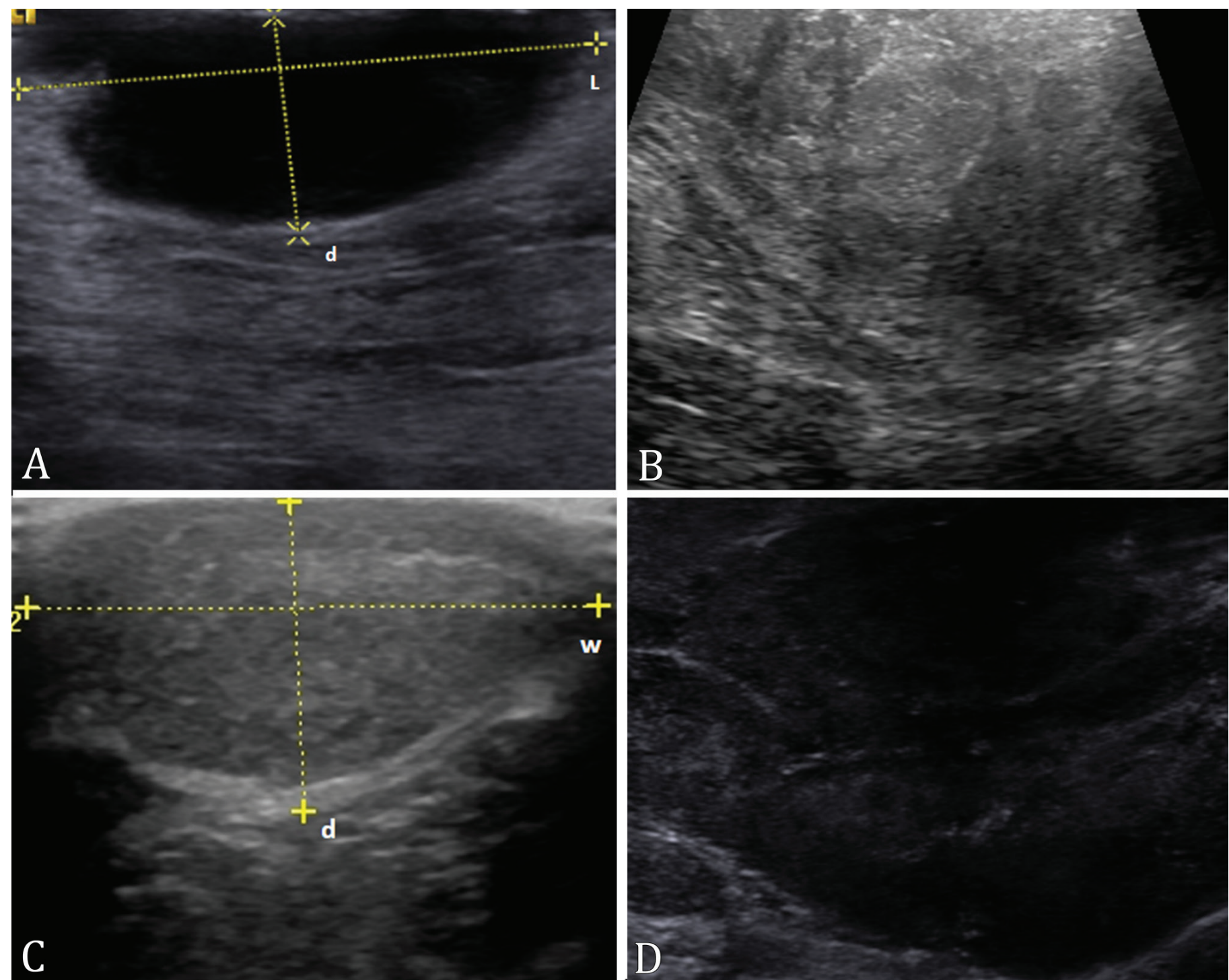

Fig.1 (A-D) Ultrasound image of canine cutaneous neoplasms evaluation. (A) Image in longitudinal section with dashed lines demonstrating the measurement of length (L) and depth (d). Neoplasm predominantly hypoechogenic, homogeneous, regular, non-invasive and without surrounding hyperechogenic structure. (B) Neoplasm predominantly hyperechogenic and heterogeneous, with rough texture. (C) Crosssectional image with dashed lines demonstrating the measurement of width (w) and depth (d). Neoplasm predominantly hypoechogenic, slightly irregular and heterogeneous, with delicate texture and without signs of invasiveness in adjacent tissues. (D) Neoplasm predominantly hypoechogenic, heterogeneous, irregular, with rough texture and absence of surrounding hyperechogenic structure. 
capsules, such as schwannomas and pheochromocytomas (Cruz et al. 2015, Tessele \& Barros 2016). Malignant neoplasms are more likely to infiltrate surrounding tissues (Henriques et al. 2009), and this characteristic could be observed in the present study by ultrasonography imaging, with significant association. This information must be used with caution, because some benign lesions, like lipoma, that may show infiltrative characteristics (Bastos et al. 2017).

The association between $\mathrm{D} / \mathrm{W}$ ratio and malignancy has already been established for female mammary tumors (Tagawa et al. 2016), as well as the width/length ratio (Feliciano et al. 2018). The lack of association of these variables in the present study could probably be due to the fact that neoplasms were included in different origins and stages, and the association of this ratio would only be reliable if it was performed by monitoring tumor progression.

Although it is not possible to make a definitive diagnosis of cutaneous neoplasms by ultrasound, this exam can be used as a complement in therapeutic screening to check for possible malignancy, considering that both the association with echogenicity and echotexture obtained good sensitivity values (73.33\% and 100\%, respectively). While an association with invasiveness in adjacent tissues is observed, caution should be exercised in the diagnostic interpretation, as this association obtained only $50 \%$ sensitivity.

Due to the fact that the histopathological exam is considered the test of choice for cutaneous neoplasms diagnosis (Graf et al. 2018), only twenty neoplasms were diagnosed using this method in this study. For this reason, an agreement test was performed in those cases that had both cytopathological and histopathological results, obtained perfect agreement and increasing the reliability of the cytopathological results.

Even though an association between echogenicity, echotexture and invasiveness with malignancy was observed in this study, these data should not be used as an isolated feature for the diagnosis of cutaneous neoplasms in dogs, since none of the associations had excellent predictive values. The low experimental number is considered a limiting factor that may increase the chances of error (Scattone \& Fava 2014) and, therefore, it was not possible to associate the sonographic characteristics with malignancy in specific types of neoplasms or in the melanocytic and epithelial origins.

Table 2. Ultrasonographic characteristics of dog cutaneous neoplasms associated with malignancy determined by cytopathological and/or histopathological results

\begin{tabular}{|c|c|c|c|c|c|c|}
\hline Characteristic & $P$ value* & Se $(\%)$ & Sp $(\%)$ & Ac $(\%)$ & PPV (\%) & NPV $(\%)$ \\
\hline Echogenicity & 0.016 & 73.33 & 66.66 & 22.19 & 84.61 & 50.00 \\
\hline Echotexture & 0.019 & 100.00 & 25.00 & 30.1 & 76.92 & 100 \\
\hline Border regularity & 0.187 & - & - & - & - & - \\
\hline Invasiveness & 0.048 & 50 & 83.33 & 15.23 & 88.23 & 40.00 \\
\hline
\end{tabular}

Hyperechogenic contour

0.168

$-$

0.962

Wepth

0.770

Depth/width ratio

* Statistically significant; (-) not applicable; Se = sensibility, Sp = specificity, PPV = positive predictive value, NPV = negative predictive value.
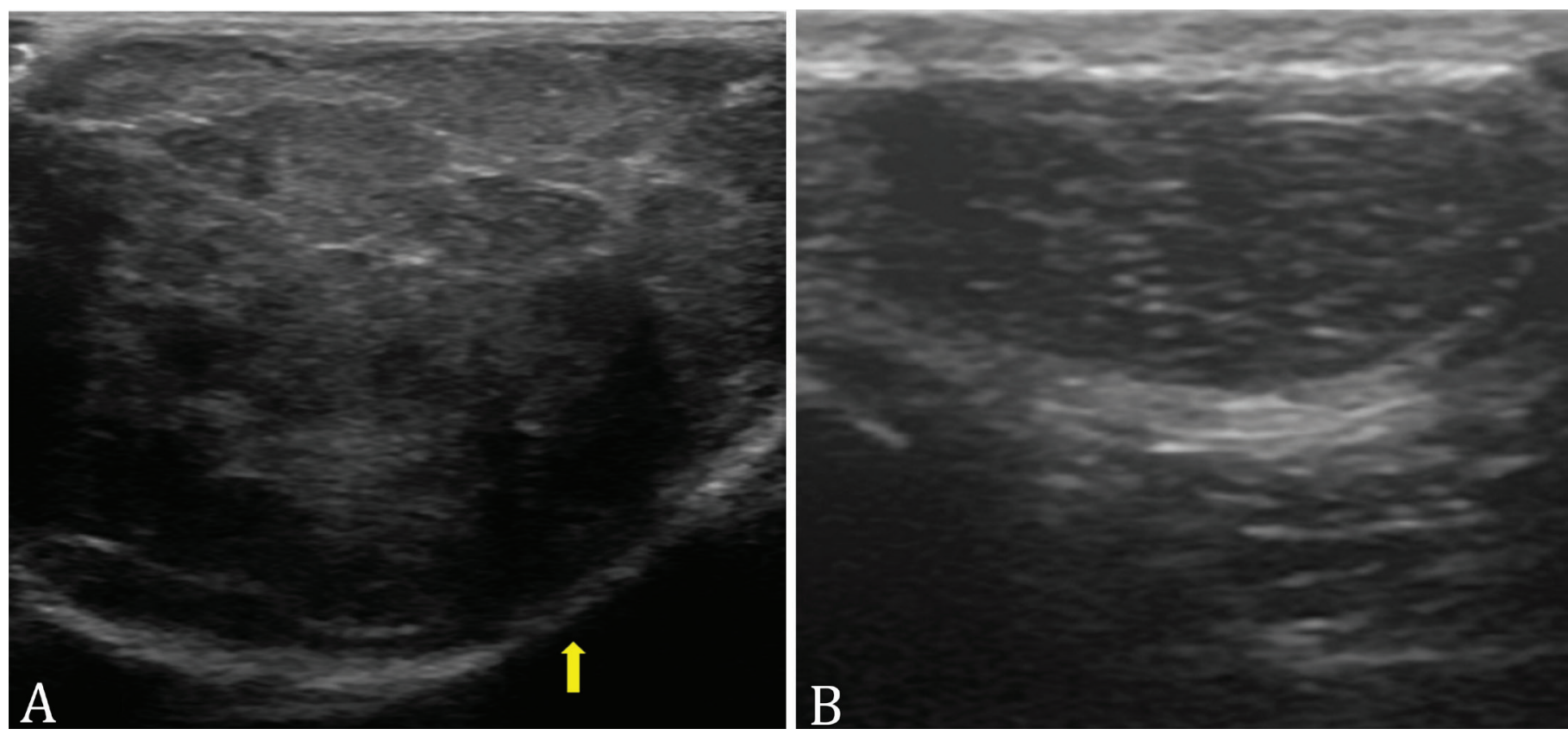

Fig.2 (A) Neoplasm predominantly hypoechogenic, heterogeneous, with hyperechogenic contour (yellow arrow) and regular borders. (B) Neoplasm predominantly hypoechogenic, heterogeneous, with regular limits and without hyperechogenic contour. 
Finally, other ultrasound methods have shown promising results in the evaluation of canine mammary neoplasms, such as Doppler ultrasonography, elastography and contrastedenhanced ultrasound (Feliciano et al. 2012, 2017, 2018). Also, it is believed that, in the future, these techniques can also be studied and implemented in the study of canine skin cancer.

\section{CONCLUSIONS}

It was possible to verify differences between benign and malignant cutaneous neoplasms through B-mode ultrasound, since the malignant neoplasms were mostly hypoechogenic, heterogeneous and with signs of invasiveness in adjacent tissues.

The authors emphasize that this is a preliminary study with a small experimental number, and it presented moderate predictive values for the associations obtained. Therefore, the results should be used with caution and only to assist in the diagnosis of this condition, until further studies with a greater number and variety of cutaneous neoplasms in dogs are carried out.

\section{AUTHOR CONTRIBUTIONS}

Conception and Design: Igor Cezar Kniphoff da Cruz, Maria Lígia de Arruda Mestieri.

Ultrasound evaluation: Igor Cezar Kniphoff da Cruz, Maria Lígia de Arruda Mestieri, Ingrid Rios Lima Machado.

Cytopathological analysis: Mauren Picada Emanuelli.

Histopathological analysis: Maria Elisa Trost.

Drafting the Article: Igor Cezar Kniphoff da Cruz, João Paulo da Exaltação Pascon, Maria Lígia de Arruda Mestieri, Etiele Maldonado Gomes.

Revising Article for Intellectual Content: Igor Cezar Kniphoff da Cruz, João Paulo da Exaltação Pascon, Maria Lígia de Arruda Mestieri, Etiele Maldonado Gomes.

Acknowledgements.- This study was financed in part by the "Coordenação de Aperfeiçoamento de Pessoal de Nível Superior" (CAPES), Brazil, and “Fundação de Amparo à Pesquisa do Estado do Rio Grande do Sul” (FAPERGS), Brazil.

Conflict of interest statement.- The authors declare having no competing interests.

\section{REFERENCES}

Badea R., Crisan M., Lupsor M. \& Fodor L. 2010. Diagnosis and characterization of cutaneous tumors using combined ultrasonographic procedures (conventional and high resolution ultrasonography). Med. Ultrason. 12(4):317-322. <PMid:21210018>

Barcaui E.O., Carvalho A.C.P., Piñeiro-Maceira J., Valiante P.M. \& Barcaui C.B. 2014. High-frequency ultrasoun (22 MHz) in the evaluation of malignant cutaneous neoplasms. Surg. Cosmet. Dermatol. 6(2):105-111.

Bastos R.S.C., de Farias K.M., Lopes C.E.B., Pacheco A.C.L. \& Viana D.A. 2017. Estudo retrospectivo de neoplasias cutâneas em cães da região metropolitana de Fortaleza. Revta Bras. Hig. Sanid. Anim. 11(1):39-53. <https://dx.doi. org/10.5935/1981-2965.20170005>

Cruz T.P.P.S., Cruz F.A.C.S., Lima S.R., Ruiz T. \& Souza R.L. 2015. Schwannoma maligno cutâneo em canino. Acta Vet. Bras. 9(2):185-189.

Dobson J.M. \& Scase T.J. 2007. Advances in the diagnosis and management of cutaneous mast cell tumours in dogs. J. Small Anim. Pract. 48(8):424-431. <https://dx.doi.org/10.1111/j.1748-5827.2007.00366.x><PMid:17559522>
Feliciano M.A.R., Uscategui R.A.R., Maronezi M.C., Maciel G.S., Avante M.L., Senhorello I., Mucédola T., Gasser B., Carvalho C.F. \& Vicente W. 2018. Accuracy of four ultrasonography techniques in predicting histopatological classification of canine mammary carcinomas. Vet. Radiol. Ultrasound 59(4):444-452. <https://dx.doi.org/10.1111/vru.12606><PMid:29430763>

Feliciano M.A.R., Uscategui R.A.R., Maronezi M.C., Simões A., Silva P., Gasser B., Pavan L., Carvalho C.F., Canola J.C. \& Vicente W. 2017. Ultrasonography methods for predicting malignancy in canine mammary tumours. PLoS One 12(5):e0178143. <https://dx.doi.org/10.1371/journal.pone.0178143> $<$ PMid:28542533>

Feliciano M.A.R., Vicente W.R.R. \& Silva M.A.M. 2012. Conventional and Doppler ultrasound for the differentiation of benign and malignant canine mammary tumours. J. Small Anim. Pract. 53(6):332-337. <https://dx.doi. org/10.1111/j.1748-5827.2012.01227.x><PMid:22647211>

Feliciano M.A.R., Vicente W.R.R., Leite C.A.L. \& Silveira T. 2008. Abordagem ultrassonográfica da neoplasia mamária em cadelas: revisão de literatura. Revta Bras. Reprod. Anim. 32(3):197-201.

Figueiredo C.R.L.V. 2019. The unusual paradox of cancer-associated inflammation: an update. J. Bras. Patol. Med. Lab. 55(3):321-332. <https:// dx.doi.org/10.5935/1676-2444.20190029>

Garcia D.A.A., Froes T.R. \& Guérios S.D. 2012. Ultrassonografia abdominal pré-operatória em cães e gatos com suspeita de tumores abdominais. Ciência Rural 42(1):105-111. <https://dx.doi.org/10.1590/S010384782012000100017>

Graf R., Pospischil A., Guscetti F., Meier D., Welle M. \& Dettwiler M. 2018. Cutaneous tumors in swiss dogs: retrospective data from the swiss canine cancer registry, 2008-2013. Vet. Pathol. 55(6):809-820. <https://dx.doi. org/10.1177/0300985818789466><PMid:30131007>

Henriques A.C.G., Cazal C., Fonsêca D.D.D., Bello D.M.A., Araújo N.C. \& Castro J.F.L. 2009. Considerações sobre classificação e o comportamento biológico dos tumores odontogênicos epiteliais: revisão de literatura. Revta Bras. Cancerol. 55(2):175-184.

Khalbuss W.E., Teot L.A. \& Monaco Sara E. 2010. Diagnostic accuracy and limitations of fine-needle aspiration cytology of bone and soft tissue lesions. Cancer Cytopathol. 118(1)24-32. <https://dx.doi.org/10.1002/ cncy.20058> <PMid:20091838>

Kleinerman R., Whang T.B., Bard R.L. \& Marmur E.S. 2012. Ultrasound in dermatology: principles and applications. J. Am. Acad. Dermatol. 67(3):478487. <https://dx.doi.org/10.1016/j.jaad.2011.12.016><PMid:22285673>

Kučinskienė V., Samulènienė D., Gineikienė A. Raišutis R., Kažys R. \& Valiukevičienè S. 2014. Preoperative assessment of skin tumor thickness and structure using 14-MHz ultrasound. Medicina 50(3):150-155 <https://dx.doi.org/10.1016/j.medici.2014.08.002><PMid:25323542>

Loh Z.H.K., Allan G.S., Nicoll R.G. \& Hunt G.B. 2009. Ultrasonographic characteristics of soft tissue tumours in dogs. Aust. Vet J. 87(8):323-329. <https://dx.doi.org/10.1111/j.1751-0813.2009.00460.x><PMid:19673848>

Longo M., Bavcar S., Handel I., Smith S. \& Liuti T. 2018. Real-time elastosonography of lipomatous vs. malignant subcutaneous neoplasms in dogs: preliminary results. Vet. Radiol. Ultrasound 59(2):198-202.<https://dx.doi.org/10.1111/ vru.12588><PMid:29271127>

Merlo D.F., Rossi L., Pellegrino C., Ceppi M., Cardelinno U., Capurro C., Ratto A., Sambucco P.L., Sestito V., Tanara G. \& Bocchini V. 2008. Cancer incidence in pet dogs: findings of the animal tumor registry of Genoa, Italy. J. Vet. Intern. Med. 22(4):976-984.<https://dx.doi.org/10.1111/j.1939-1676.2008.0133.x> <PMid:18564221>

Nyman H.T., Nielsen O.L., McEvoy F.J., Lee M.H., Martinussen T., Hellmén E. \& Kristensen A.T. 2006. Comparison of B-mode and Doppler ultrasonographic findings with histologic features of benign and malignant mammary tumours in dogs. Am. J. Vet. Res. 67(6):985-991. <https://dx.doi.org/10.2460/ ajvr.67.6.985><PMid:16740091> 
Reginelli A., Belfiore M.P., Russo A., Turriziani F., Moscarella E., Troiani T., Brancaccio G., Ronchi A., Giunta E., Sica A., Lovino F., Ciardiello F., Franco R., Argenziano G., Grassi R. \& Cappabianca S. 2020. A preliminary study for quantitative assessment with HFUS (high-frequency ultrasound) of nodular skin melanoma Breslow thickness in adults before surgery: interdisciplinary team experience. Curr. Radiopharm. 13(1):48-55. <https://dx.doi.org/10 $.2174 / 1874471012666191007121626><$ PMid:31589132>

Roldán F.A. 2014. Ultrasound skin imaging. Actas Dermo-Sifiliográficas 105(10):891-899. <https://dx.doi.org/10.1016/j.ad.2013.11.015> $<$ PMid:24838227>

Rosseto V.J.V., Moreno K., Grotti C.B., Reis A.C.F. \& Bracarense A.P.F.R.L. 2009. Frequency of tumours in dogs based on cytological diagnosis: a retrospective study in a veterinary teaching hospital. Semina, Ciênc. Agrárias 30(1):189200. <https://dx.doi.org/10.5433/1679-0359.2009v30n1p189>

Scattone N.V. \& Fava C.D. 2014. Casuística de tumores cutâneos em cães diagnosticados pelo Laboratório de Anatomia Patológica do Instituto Biológico, São Paulo, Brasil, no período de 1996 a 2013. Revta Acad., Ciênc. Agrár. Ambient. 12(4):296-305. <https://dx.doi.org/10.7213/ academica.12.04.A008>

Simeonov R.S. 2010. The accuracy of fine-needle aspiration cytology in the diagnosis of canine skin and subcutaneous masses. Comp. Clin. Pathol. 21(2):143-147. <https://dx.doi.org/10.1007/s00580-010-1075-5>

Tagawa M., Kanai E., Shimbo G., Kano M. \& Kayanuma H. 2016. Ultrasonographic evaluation of depth-width ratio (D/W) of benign or malignant mammary tumours in dogs. J.Vet. Med. Sci. 78(3):521-524.<https://dx.doi.org/10.1292/ jvms.15-0456><PMid:26596466>

Tessele B. \& Barros C.S.L. 2016. Tumores em bovinos encontrados em abatedouros frigoríficos. Pesq. Vet. Bras. 36(3):145-160. <https://dx.doi. org/10.1590/S0100-736X2016000300002>

Veronese L.A., Corrente J.E. \& Marques M.E.A. 2007. Critérios histopatológicos para diagnóstico de melanoma maligno cutâneo: análise comparativa de sua frequência em lesões benignas e melanomas de pequena espessura $(<2 \mathrm{~mm})$. J. Bras. Patol. Med. Lab. 43(5):363-368. <https://dx.doi.org/10.1590/ S1676-24442007000500009>

Villamil J.A., Henry C.J., Bryan J.N., Ellersieck M., Schultz L., Tyler J.W. \& Hahn A.W. 2011. Identification of the most common cutaneous neoplasms in dogs and evaluation of breed and age distributions for selected neoplasms. J. Am. Vet. Med. Assoc. 239(7):960-965. <https://dx.doi.org/10.2460/ javma.239.7.960><PMid:21961635>

Wahie S. \& Lawrence C.M. 2007. Wound complications following diagnostic skin biopsies in dermatology inpatients. Arch. Dermatol. 143(10):1267-1271. <https://dx.doi.org/10.1001/archderm.143.10.1267><PMid:17938340>

Wratten C.R., O'Brien P.C., Hamilton C.S., Bill D., Kilmurray J. \& Denham J.W. 2007. Breast edema in patients undergoing breast-conserving treatment for breast cancer: assessment via high frequency ultrasound. Breast J. 13(3):266-273. <https://dx.doi.org/10.1111/j.1524-4741.2007.00420.x> 